\title{
Adapting MAIN to Irish (Gaeilge)
}

\author{
Mary-Pat O'Malley \\ National University of Ireland
}

\section{Stanislava Antonijevic}

National University of Ireland

Irish (Gaeilge) is the first official language of the Republic of Ireland. It is a fast-changing, endangered language. Almost universal bilingualism (i.e. almost all Irish speakers also speak English), frequent code-switching to English, and loan words are features of the sociolinguistic context in which the language is spoken. This paper describes the adaptation of the Language Impairment Testing in Multilingual Settings - Multilingual Assessment Instrument for Narratives (LITMUS-MAIN, Gagarina et al., 2019) to Irish. Data was collected using the retell mode (Cat story) and the comprehension questions. Eighteen children participated ranging in age from 5;3 to 8;7 (six female and 12 male). Results suggest that story structure is not sensitive to exposure to Irish at home and indicate that MAIN Gaeilge (Irish) is a promising tool for assessing language in Irishspeaking children from a range of Irish language backgrounds.

\section{Introduction}

Language assessment is a complex task requiring clinicians to distinguish between typical and atypical development across a range of language domains including syntax, semantics, morphology, and pragmatics. For multilingual children, language assessment requires clinicians to distinguish between language differences (compared to monolinguals) associated with multilingualism, length and amount of exposure, and genuine language impairments (Kohnert, 2013; Li'el, Williams \& Kane 2020). In order to do this, clinicians rely on a range of measures from norm-referenced standardised tests to criterion-referenced language measures (Ebert \& Scott, 2014). Norm-referenced tests have long been identified as inadequate for assessing language in multilingual children due to cultural, content, and linguistic bias (De Lamo White \& Jin 2011). Accurate assessment of multilingual children continues to be a critical need for clinicians as global demographics have changed and continue to do so (Peña, Gillam \& Bedore, 2014; Rethfeld, 2019; Wiefferink, van Beugen, Sleeswijk \& Gerrits, 2020). 
The importance of narrative as a component of language assessment is well-recognised as is the relationship between narrative development, literacy, and academic success (Boudreau, 2008; Pinto, Tarchi \& Bigozzi, 2018). Narratives are considered a more authentic means of assessing children's language than traditional measures (Justice, Bowles, Pense \& Goss, 2010). Furthermore, as narratives are common across cultures, they can provide a language assessment context that is likely to result in lower levels of test bias than traditional standardised testing (Peña, Gillam \& Bedore, 2014).

The Language Impairment Testing in Multilingual Settings - Multilingual Assessment Instrument for Narratives (LITMUS-MAIN; henceforth MAIN, Gagarina et al., 2012; 2015; 2019) was developed in order to assess narrative comprehension and production in bilingual children aged 3-10 years. It was developed by the Narrative and Discourse working group of COST Action IS0804 (a trans-European research network) as part of the LITMUS test battery (Armon-Lotem, de Jong \& Meir, 2015). The MAIN (Gagarina et al., 2012; 2019) allows clinicians to assess a range of linguistic features in context: macrostructure (the story grammar components of goal (G), attempt (A), outcome (O), and internal states which initiate the goal (IST as IE) and express the reaction (IST as R) based on Stein and Glenn (1979)) and microstructure (lexical diversity and aspects of morpho-syntax) (Gagarina, et al., 2015). It is assumed that macrostructure is universal and not language specific. For example, Boerma, Leseman, Timmermeister, Wijnen and Blom (2016) found equal performance of monolingual and bilingual children on MAIN (Gagarina et al., 2012) demonstrating that measures of macrostructure tend not to be affected by factors such as length of exposure. While some studies show that macrostructure scores tend to increase with age (Bohnacker, 2016; Gagarina, 2016; Kapalková, Polišenská \& Marková, 2016), other studies have found that this applies only to story complexity and comprehension scores and not to story structure and internal state terms (ISTs) (Maviş et al., 2016). In a pilot study, Gagarina et al. (2015) found no differences in story structure scores across a number of language pairings even when children had varying levels of ability in their two languages. However, other studies have reported stronger performance in the dominant language for younger children, differences which were not (as) evident in older children (Bohnacker, 2016; Roch et al., 2016).

\section{A brief description of the Irish language: a focus on morpho-syntax}

Irish is a Celtic, VSO language. The basic order of elements is: Verb + Subject $+\mathrm{X}$ where $\mathrm{X}$ can be object, indirect object, adverbial, prepositional phrase, verbal noun, and so on (Hickey, 2012). Negatives and interrogatives are marked by the appropriate particle in front of the verb. Apart from the 11 irregular verbs, the verb pattern is highly regular. The Irish alphabet has 18 letters. Extended vowel length is signalled by a length mark over the vowel, known as a fada. For example: the word for 'hand' is lámh [lo:v] while the word for 'hat' is hata [hata]. It has a relatively high phoneme count with variations in pronunciation between the three main dialects (Ulster, Munster, and Connaught). Further dialectal variations are found within each of those 
three main dialects. Irish educational authorities explicitly recognise local dialects as the target variety for pre-schools in Gaeltacht areas (Ó Murchadha, 2016).

Initial consonant mutations (IMs) for expressing grammatical functions such as verb inflections, case, number, and gender agreement with prepositions, articles, and adjectives are a prominent feature of the language (see Müller, Muckley \& Antonijevic-Elliott, 2019 for further details on IM). Irish is undergoing a rapid process of language change at present, and the IM system is affected by this process in that many fluent Irish speakers show inconsistent use of IMs in their spoken language (Müller et al., 2019). Additional language changes in each new generation of speakers have been documented including frequent code switching to English and the use of loan words, idioms, and direct translations from English (Ó Catháin, 2016; Pétrváry et al., 2014). As a result of this rapid language change, the quality of language exposure for children acquiring Irish is variable and does not necessarily conform to the formal grammatical standards. Because of that, it is difficult to decide upon the criteria for assessing grammatical accuracy in children's language (Antonijevic, Muckley \& Müller, 2020; Nic Fhlannchadha \& Hickey, 2019). Therefore, using MAIN Gaeilge (Irish) and focussing on the macrostructure measures might be more efficient in distinguishing between Irish-speaking children with typical language development and those with Developmental Language Disorder (DLD).

\subsection{The Irish language: current sociolinguistic context}

Irish is a threatened, fast-changing minority language. It is the first official language of the Republic of Ireland. English is the second official language and the dominant majority language. In the 2016 Irish Census, $1.7 \%$ of respondents (73,803 individuals) reported speaking Irish on a daily basis outside of the education system (Central Statistics Office, 2017). Almost all children speaking Irish as their first language (L1) are growing up bilingually, as they can also speak their second language (L2, English) competently by the time they reach middle childhood, i.e. 6-13 years of age (Nic Fhlannacha \& Hickey, 2019). O'Toole and Hickey (2016) noted universal bilingualism among Irish speakers for over two decades and remarked on the current rarity of monolingualism among Irish speakers. The profile of Irish speakers has changed from traditional, rural, native speakers to encompass "growing numbers of young, middle class, urban L2 speakers” (O’Toole \& Hickey, 2016: 147).

While the reality of almost universal bilingualism is generally accepted, it is difficult to define the exact Age of Acquisition (AoA) of English as children tend to be exposed to English from an early age: in their wider community, via extended family, mass media, and public services (Hickey, 2007; 2016). It is also difficult to accurately identify the amount of exposure to Irish and English due to the dominant use of English by the general population and frequent code-switching in the Irish-English bilingual communities. High levels of contact between the two languages is believed to have given rise to the current sociolinguistic context for Irish (Hickey, 2007). Another potentially contributing factor is the relative morpho-syntactic complexity of Irish which has been described briefly above. Density of Irish speakers is highest in the Gaeltacht areas, the districts officially recognised by the Government of Ireland as Irish- 
speaking communities. In these districts, over $60 \%$ of people stated that they could speak Irish while $21 \%$ reported that they speak Irish daily outside of education (CSO, 2017).

\subsection{The Irish language and education}

According to recent reports, a total of 252 Irish-medium primary schools catering for 45,568 pupils are in operation in the Republic of Ireland. Of these, 105 schools (7,633 pupils) are in the Gaeltacht areas while 147 schools (37,935 pupils) are located outside of Gaeltacht areas (Department of Education \& Skills 2019). In terms of state support, the Department of Education and Skills Policy on Gaeltacht Education 2017-2022 forms part of the government's 20-year strategy for the Irish language to maintain and extend the use of Irish as a spoken language. Children growing up in Gaeltacht areas typically attend local Irish-medium preschools (naíonraí) and schools (Gaelscoileanna). However, research suggests that there is significant variation in the amount of Irish spoken in different Irish-medium education settings (Hickey, 2001; 2007). Due to demographic changes in Gaeltacht areas, children in these areas attending Irish-medium education are likely to have varying exposure to Irish at home. The exposure can range from predominantly Irish to predominantly English exposure at home (Mac Donnacha, Ní Chualáin, Ní Sheaghdha \& Ní Mhainín, 2004). As a result, Irishmedium primary schools in Gaeltacht areas tend to show variability in their adherence to Irishmedium teaching as classes contain both children with Irish as L1 and children with Irish as L2 (Nic Fhlannchadha \& Hickey, 2019). On the other hand, most children attending Irishmedium schools outside of Gaeltacht areas have no or minimal amount of Irish at home, and in that sense form a homogenous group immersed in Irish at the same time and with equivalent language exposure (Antonijevic, Durham \& Ni Chonghaile, 2017).

\section{$3 \quad$ Adapting MAIN to Irish}

Given the specific sociolinguistic context in Ireland outlined above, we needed to take the influence of English and universal bilingualism into account when adapting MAIN to Irish. Therefore, we decided to develop a bilingual adaptation, MAIN Gaeilge (Irish). This bilingual version contains the instructions in English (the same as the English version of MAIN), Irish and English versions of the parental questionnaire, story scripts in Irish, and scoring forms with titles and concepts in English while the examples of correct and incorrect response are given in Irish. The decision to produce a bilingual adaptation was informed by a range of factors. All speech and language therapists working with bilingual Irish-English children are themselves bilingual Irish-English speakers. Programmes for the professional qualification of speech and language therapists in Ireland are delivered exclusively through English and as a result speech and language therapists acquire relevant linguistic terminology only in English. Therefore, we felt that having the administration instructions in English and bilingual scoring sheets, particularly for story structure and story complexity, would render the process of administration and scoring more accessible for speech and language therapists. We kept terms such as G, A, 
O, IST, structural complexity, retelling etc. in English on the forms. An additional reason for bilingual scoring sheets is that speech and language therapists working with Irish-speaking families have varying levels of written language proficiency. Similarly, some parents raising their children through Irish may be more confident readers in English and may prefer to complete the parental questionnaire in English. These are the factors which informed the decision to produce a bilingual adaptation. We wish to acknowledge the input of Anna Ní Choirbín, Gearóid Ó Cadhain, and Kevin Conboy for the adaptation of the parental questionnaire to Irish. We wish in particular to acknowledge Anna Ní Choirbín for her assistance with naturalness of the story scripts and comprehension questions, and for assistance with questions of grammatical accuracy and spelling.

As outlined in the instructions for the adaptation of MAIN (Bohnacker \& Gagarina, 2019), we only began the adaptation once we were thoroughly familiar with the manual and the entire instrument. Using the revised 2019 English version (Gagarina et al., 2019) as the template, we adapted the story scripts to Irish. We opted to adapt MAIN to the Irish language rather than complete a direct translation due to the issues associated with translation of tests from one language to another identified by Paradis, Crago, and Genesee (2011). An accepted unitary norm for spoken Irish does not exist and the "absence of diverse local and regional written norms based on the de facto target spoken models of the Gaeltacht dialects" has been noted (Ó Murchadha, 2016:208). As mentioned above, there are three Gaeltacht dialects: Connaught Irish, Munster Irish, and Ulster Irish. For this version of MAIN Gaeilge (Irish), we used the Connaught and Munster dialects. In future, we plan to include Ulster Irish variations in the scoring sheets.

We kept the GAO sequences and ISTs for each protagonist consistent with the English version, and aimed to keep the number of words per story as close to the English as possible within the constraints of the language. See Table 1 for comparisons of the English and Irish versions in relation to number of words per story. The adaptation of the story scripts was checked carefully by two members of the team to ensure naturalness and we arrived at the final version through consensus. This meant that rather than a direct translation, we adapted the stories to sound natural in the dialects while still preserving the content of the stories. We also preserved the same logical sequence of clauses and utterances. With respect to lexicon, we used basic level terms based on the experience of both team members and O'Toole and Fletcher (2012).

Table 1: Comparison of the number of words across the MAIN-stories (Gagarina et al., 2019).

\begin{tabular}{|l|l|l|}
\hline Story & $\begin{array}{l}\text { \# of words in } \\
\text { English }\end{array}$ & $\begin{array}{l}\text { \# of words in } \\
\text { Irish }\end{array}$ \\
\hline Cat & 178 & 213 \\
\hline Dog & 174 & 207 \\
\hline Baby Birds & 178 & 206 \\
\hline Baby Goats & 185 & 201 \\
\hline
\end{tabular}

The main focus to date has been on macrostructure given the need for an assessment tool that is not sensitive to the variations relevant to the Irish context outlined above (i.e. the varying 
language backgrounds of children in Irish-medium education and the fact that the language itself is in the process of rapid change). Regarding microstructure we have kept the number of ISTs and direct speech sentences the same overall and have endeavoured to keep the number of subordinating and co-ordinating constructions (+/- 2) as close to the English version as possible within the constraints of the language. The Cat story is presented in both languages in Table 2 as an example of the adaptation to Irish.

Table 2: The three episodes of Cat story in Irish and English with GAO and ISTs identified. The marking of story structure components and internal state terms is marked in the text as per the MAIN manual (Gagarina et al., 2019) i.e.: (goal attempt. outcome internal state terms).

\begin{tabular}{|c|c|c|}
\hline Pictures & ish Total \# of words 213 & English Total \# of words 178 \\
\hline 1,2 & $\begin{array}{l}\text { Lá amháin, bhí cat spraíuil ann a chonaic } \\
\text { féileacán buí ina shuí ar thor. Léim sé amach } \\
\text { mar bhí Sé ag iarraidh greim a fháil air. Idir } \\
\text { an dá linn, bhí buachaill gealgháireach ag } \\
\text { teacht ar ais ó bheith ag iascaireacht le } \\
\text { buicéad agus liathróid ina lámha aige. } \\
\text { D'fhéach sé ar an gcat ag dul i ndiaidh an } \\
\text { fhéileacáin. }\end{array}$ & $\begin{array}{l}\text { One day there was a playful cat who } \\
\text { saw a yellow butterfly sitting on a } \\
\text { bush. He leaped forward because he } \\
\text { wanted to catch it. Meanwhile, a } \\
\text { cheerful boy was coming back from } \\
\text { fishing with a bucket and a ball in his } \\
\text { hands. He looked at the cat chasing } \\
\text { the butterfly. }\end{array}$ \\
\hline 3, & $\begin{array}{l}\text { D'eitil an féileacán leis go tapa agus thit an } \\
\text { cat isteach sa tor. Ghortaigh sé é féin agus bhí } \\
\text { an-fhearg air. Baineadh geit as an mbuachaill } \\
\text { agus thit an liathróid amach as a lámh. Nuair } \\
\text { a chonaic sé a liathróid ag rolladh isteach san } \\
\text { uisce, lig sé béic as, ag rá: "Ó, ná habair, seo } \\
\text { léi mo liathróid." Bhí brón air agus bhí sé ag } \\
\text { iarraidh a liathróid a fháil ar ais. Idir an dá } \\
\text { linn, thug an cat buicéad an bhuachalla faoi } \\
\text { deara agus chuimhnigh sé air féin: "Tá mise } \\
\text { ag iarraidh iasc a sciobadh.". }\end{array}$ & $\begin{array}{l}\text { The butterfly flew away quickly and } \\
\text { the cat fell into the bush. He hurt } \\
\text { himself and was very angry. The boy } \\
\text { was so startled that the ball fell out of } \\
\text { his hand. When he saw his ball rolling } \\
\text { into the water, he cried: "Oh no, there } \\
\text { goes my ball". He was sad and } \\
\text { wanted to get his ball back. } \\
\text { Meanwhile, the cat noticed the boy's } \\
\text { bucket and thought: "I want to grab a } \\
\text { fish." }\end{array}$ \\
\hline 5,6 & $\begin{array}{l}\text { Ag an am céanna, thosaigh an buachaill ag } \\
\text { tarraingt a liathróide amach as an uisce lena } \\
\text { shlat iascaigh. Níor thug sé faoi deara go } \\
\text { raibh an cat tar éis a iasc a sciobadh. Ar } \\
\text { deireadh, bhí an cat an-sásta leis féin iasc } \\
\text { chomh blasta a ithe agus bhí áthas ar an } \\
\text { mbuachaill a liathróid a fháil ar ais. }\end{array}$ & $\begin{array}{l}\text { At the same time the boy began } \\
\text { pulling his ball out of the water with } \\
\text { his fishing rod. He did not notice that } \\
\text { the cat had grabbed a fish. In the end, } \\
\text { the cat was very pleased to eat such a } \\
\text { tasty fish and the boy was happy to } \\
\text { have his ball back. }\end{array}$ \\
\hline
\end{tabular}

With respect to the scoring forms, as there are numerous possibilities for describing $\mathrm{G}, \mathrm{A}$, or O in Irish and as we could not anticipate all possible responses, we therefore added an instruction in English in the scoring sheet to the effect that other acceptable responses could be considered. We decided to do this so that researchers and speech and language therapists using MAIN 
Gaeilge (Irish) could score responses from children that were not included in the list of correct responses, but still adhered to the desired element $\mathrm{G}$, A, O. With respect to the ten comprehension questions, they were adapted to Irish with a focus on sounding natural while continuing to maintain the questions' focus on the specific goal or internal state term as initiating event or reaction.

\section{Piloting MAIN: Gaeilge (Irish)}

Antonijevic, O'Connell, Randle and O’Malley-Keighran (submitted) examined production and comprehension of narrative macrostructure using MAIN Gaeilge (Irish). Eighteen Irish-English bilingual participants ( 6 female and 12 male), age 5;3 - 8;7 who attended Irish-medium schools were assessed with the Cat story in the retelling elicitation mode, followed by the ten comprehension questions. For this study, story structure, ISTs, and comprehension were analysed. The average narrative story structure scores were compared to the scores of previous studies that also used the retelling mode and whose participants were immersed in their L2 via their education (Roch et al., 2016; Maviş et al., 2016). A comparison of scores for story structure, ISTs, and comprehension are presented in Table 3. While the mean story structure score for Irish was higher than in the other two studies and the mean ISTs score was relatively similar, the mean comprehension score was lower. Participants' age, exposure to Irish at home, socioeconomic status, birth order, and the number of siblings did not influence the story structure scores, IST score and the comprehension score. Therefore, the current findings suggest that the story structure scores may not be sensitive to children's language exposure at home when they attend immersion education. While additional data are needed to further explore the influence of exposure to Irish at home and in the broader community on the narrative production and comprehension, these early findings suggest that MAIN Gaeilge (Irish) is not sensitive to the variability of exposure to Irish at home and therefore open a possibility that MAIN Gaeilge (Irish) could be used as part of language assessment for all children attending Irish-medium schools across the country.

Table 3: Means and standard deviations (SDs) for story structure, IST and comprehension obtained in studies by Antonijevic et al. (submitted) for Irish, Roch et al. (2016) for Italian and English, and Mavis et al. (2016) for Turkish.

\begin{tabular}{|l|l|l|l|l|}
\hline & $\begin{array}{l}\text { Antonijevic et al. } \\
\text { (submitted) }\end{array}$ & \multicolumn{2}{l|}{ Roch et al. (2016)* } & $\begin{array}{l}\text { Maviş et al. } \\
\text { (2016) }\end{array}$ \\
\hline $\begin{array}{l}\text { Mean age in months } \\
\text { (SD) }\end{array}$ & $79(14.77)$ & $71.5(3.5)$ & $59(19)$ \\
\hline Language & Irish & L1 Italian & L2 English & L1 Turkish \\
\hline Story structure (SD) & $9.11(2.08)$ & 7.10 & 5.75 & $7.23(1.90)$ \\
\hline IST (SD) & $3.44(1.04)$ & 4.00 & 3.20 & $5.15(2.60)$ \\
\hline Comprehension (SD) & $5.56(2.85)$ & 8.25 & 7.00 & $7.85(2.20)$ \\
\hline
\end{tabular}

$*$ Results for the younger and older age group were averaged. 


\section{Challenges and adaptions/changes to the MAIN Gaeilge (Irish) after piloting}

In this section we briefly explore minor challenges that we experienced during administration of the MAIN Gaeilge (Irish), the minor adaptations we made to the scoring forms as a result of these challenges, and considerations for future versions of the MAIN Gaeilge (Irish).

\subsection{Challenges with the comprehension questions}

In the pilot study, almost all participants struggled with the questions focusing on internal state terms as reactions e.g., D2: How does the cat feel? We translated this as Conas a bhraitheann an cat? Conas a mhothaíonn an cat? Cén chaoi a mbraitheann an cat? Cén chaoi a bhfuil an cat ansin? These are all ways of asking 'How does the cat feel?' in Irish. However, participants still struggled to answer the question despite the fact that the tester also points to the relevant picture while asking the question. In personal conversation, Tadgh Ó hIfearnáin, professor of modern Irish at NUI Galway, suggested the following nuances: Meastú céard a bhraitheann an cat? I cén dóigh a mothaíonn an cat, dar leat? Conas atá ag an gcat, dar leat? Conas a bhraitheann an cat, dar leat? These structures invite the child's opinion e.g. 'how do you think the cat is feeling/the cat feels?' Although this is not exactly the same formulation as in the original MAIN (Gagarina et al., 2019), it is an adaptation that might be more appropriate for the Irish language context. This is an empirical question that needs to be addressed in future studies. Another potentially influencing factor related to the children's difficulties answering the comprehension questions focusing on internal state terms as reactions is the general sociolinguistic context of Irish: children's experiences with a limited number of speakers in contracting domains of use may influence their comprehension of such terms (Hickey, 2007; Nic Fhlannchadha \& Hickey, 2019).

\subsection{Adaptations to the story structure scoring and internal state terms score forms}

With respect to scoring and the sociolinguistic context outlined above, participants were occasionally found to mix the language codes in their retelling of the story (Antonjievic et al. submitted). Consider for example, the utterance in (1) (Irish is marked in bold, English in italics).

\section{(1) Léim sé thall ar an butterfly}

'he jumped over on the butterfly' (participant P 20SS06).

In the pilot study reported above (Section 4), we decided to award a score of 1 point irrespective of the language in which it was produced. Following this approach, the utterance in (1) received 1 point on the component A4 A, although the crucial noun was in English and not in Irish. This 'bilingual' approach to the scoring was not specified in the MAIN Gaeilge (Irish) manual, and we acknowledge that while it deviates from how scoring is done with MAIN (Gagarina et al., 
2015) when investigating a participant's score in one language, it does take into account the almost universal bilingualism of the Irish sociolinguistic context outlined above. The same participant also produced the utterance in (2), which received 1 point on the component A5 O.

\section{(2) an cat stuck istigh an bush}

'the cat stuck in the bush' (participant P 20SS06).

We now intend to conduct further, detailed exploration of code-switching patterns in both the data reported here and in future data as outlined below. We intend to reconsider the issue of scoring instructions in the manual in order to ensure scoring that is sensitive to the children's sociolinguistic context and patterns of language use.

Regarding ISTs, some lexical items were added to the list of possible responses after the pilot study, for example: mí-shásta 'displeased/dissatisfied', scanrúil 'frightening/frightful”) and aerach 'lively' (emotion terms), and bhí idea 'he had an idea' (mental verbs).

\section{Conclusion and future plans}

Having completed a pilot study using the MAIN Gaeilge (Irish) and added the abovementioned modifications, we now aim to systematically collect data focusing on Irish speakers from different language backgrounds:

a) children from Irish-dominant homes living in Gaeltacht areas and attending Gaelscoileanna (Irish-medium schools);

b) those from English-dominant homes living in Gaeltacht areas and attending Gaelscoileanna, and

c) those living in English-dominant areas that are immersed in Irish through education (if possible, from both Irish and from English dominant homes).

This proposed investigation would provide baseline data and guidelines for narrative assessment for Irish-speaking school-aged children from different language backgrounds. Having a single, valid, reliable, quick, and easy to administer tool that can be used for assessing language in children from different language environments would greatly improve speech and language therapy services for Irish-speakers as the current range of language assessments in Irish is limited. This proposed research will also allow us to further adjust the MAIN Gaeilge (Irish) where necessary.

\section{$7 \quad$ References}

Antonijevic, S., Durham, R., \& Ní Chonghaile, I. (2017). Language performance of sequential bilinguals on an Irish and English sentence repetition task. Linguistic Approaches to Bilingualism, 7, 359-393. 
Antonijevic, S., Muckley, S.A., \& Müller, N. (2020). The role of consistency in use of morphosyntactic forms in child-directed speech in the acquisition of Irish, a minority language undergoing rapid language change. Journal of Child Language, 47, 267-288.

Antonijevic, S., O’Connell, M., Randle, A., \& O’Malley-Keighran, M.P. (submitted). Exploring relationships between, narrative macrostructure and background factors in story organisation: MAIN in the Irish Language. Submitted to Linguistic Approaches to Bilingualism.

Armon-Lotem, S., \& de Jong, J. (2015). Introduction. In S. Armon-Lotem, J. de Jong, \& N. Meir (Eds.), Methods for Assessing Multilingual Children: Disentangling Bilingualism from Language Impairment (pp. 1-22). Bristol: Multilingual Matters.

Boerma, T., Leseman, P., Timmermeister, M., Wijnen, F. \& Blom, E. (2016). Narrative abilities of monolingual and bilingual children with and without language impairment: implications for clinical practice. International Journal of Language \& Communication Disorders, 51, 626-638.

Bohnacker, U. (2016). Tell me a story in English or Swedish: Narrative production and comprehension in bilingual preschoolers and first graders. Applied Psycholinguistics, 37(1), 19-48.

Bohnacker, U., Gagarina, N., \& Lindgren, J. (2019), Macrostructural organization of adults' oral narratives. ZAS Papers in Linguistics, 62, 190-208.

Central Statistics Office, (2017). Census 2016 Summary Results- Part 1. Retrieved on March 5th 2020 from https://www.cso.ie/en/csolatestnews/presspages/2017/census2016summaryresults-part1/.

De Lamo White, C. \& Jinn, L. (2011). Evaluation of speech and language assessment approaches with bilingual children. International Journal of Language \& Communication Disorders, 46(6), 613-627.

Department of Education \& Skills (2019) Press release: Minister McHugh announces plan to double number of students in Irish-medium education. Retrieved on May 28th 2020 from https://www.education.ie/en/Press-Events/Press-Releases/2019-press-releases/PR19-12-30.htm.

Department of Education \& Skills (2016) Policy on Gaeltacht Education 2017-2022. Retrieved on May 28 th 2020 from https://www.education.ie/en/Publications/Policy-Reports/Policy-on-Gaeltacht-Education-20172022.pdf.

Department of Education \& Skills (2013) 20 year strategy for the Irish language 2010-2030. Retrieved on May 28th 2020 from https://www.education.ie/en/Publications/Policy-Reports/20-Year-Strategy-for-the-IrishLanguage-2010-2030.pdf.

Ebert, K. \& Scott, C. (2014). Relationships between narrative language samples and norm-referenced test scores in language assessments of school-aged children. Language, Speech, \& Hearing Services in Schools, 45, $337-350$.

Gagarina, N., Klop, D., Kunnari, S., Tantele, K., Välimaa, T., Balčiūnienė, I., Bohacker, U., \& Walters, J. (2012). MAIN: Multilingual Assessment Instrument for Narratives. ZAS Papers in Linguistics, 56.

Gagarina, N., Klop, D., Kunnari, S., Tantele, K., Välimaa, T., Balčiūnienė, I., Bohnacker, U., \& Walters, J. (2015). Assessment of Narrative Abilities in Bilingual Children. In S. Armon-Lotem, J. de Jong, \& N. Meir (Eds.), Assessing multilingual children disentangling bilingualism from language impairment (pp. 243-269). Bristol: Multilingual Matters.

Gagarina, N., Klop, D., Kunnari, S., Tantele, K., Välimaa, T., Bohnacker, U., \& Walters, J. (2019). MAIN: Multilingual Assessment Instrument for Narratives. ZAS Papers in Linguistics, 63.

Gagarina, N. (2016). Narratives of Russian-German preschool and primary school bilinguals: Rasskaz and Erzaehlung. Applied Psycholinguistics, 37(1), 91-122. 
Gagarina, N., Klop, D., Tsimpli, I., \& Walters, J. (2016). Narrative abilities in bilingual children. Applied Psycholinguistics, 37, 11-17.

Hickey, T. (2001). Mixed beginners and native speakers in minority language immersion: who is immersing whom? Canadian Modern Language Review, 57(3), 443-474.

Hickey, T. M. (2007). Children's language networks and teachers' input in minority language immersion: What goes in may not come out. Language and Education, 21(1), 46-65.

Hickey, T. (2012). ILARSP: A grammatical profile of Irish. In Ball, M. Crystal, D., \& Fletcher, P. (eds.) Assessing Grammar: The Languages of LARSP. pp 149-166. Bristol: Multilingual Matters.

Irish Times (2019). Number of Primary school pupils taught through Irish at record level. Retrieved on May 27th 2020 from https://www.irishtimes.com/news/education/number-of-primary-school-pupils-taughtthrough-irish-at-record-level-1.4011570.

Justice, L., Bowles, R., Pense, K., \& Goss, C. (2010). A scalable tool for assessing children's language abilities within a narrative context: The Narrative Assessment Protocol (NAP). Early Childhood Research Quarterly, 25(2), 218-234.

Kapalková, S., Polišenská, K., Marková, L., \& Fenton, J. (2016). Narrative abilities in early successive bilingual Slovak-English children: A cross-language comparison. Applied Psycholinguistics, 37(1), 145-164.

Kohnert, K. (2013). Language disorders in bilingual children and adults. (2 ${ }^{\text {nd }}$ ed.) USA: Plural Publishing.

Li'el, Williams, Kane (2020). Identifying developmental language disorder in children from diverse linguistic backgrounds. International Journal of Speech Language Pathology, 21(6), 613-622.

Mac Donnacha, S., Ní Chualáin, F., Ní Sheaghdha, A., \& Ní Mhainín, T. (2004). Staid reatha na scoileanna Gaeltachta: A study of Gaeltacht schools 2004. Dublin, Ireland: An Chomhairle um Oideachas Gaeltachta agus Gaelscolaíochta.

Mavis, I., Tunçer, M., and Gagarina, N. (2016). Macrostructure components in narrations of Turkish-German bilingual children. Applied Psycholinguistics, 37(1), 69-89.

Müller, N., Muckley, S.A., and Antonijevic-Elliott, S., (2019). Where phonology meets morphology in the context of rapid language change and universal bilingualism: Irish initial mutations in child language. Clinical Linguistics \& Phonetics, 33(1-2), 3-19.

Nic Fhlannchadha, S. and Hickey, T.M., (2019). Assessing children's proficiency in a minority language: exploring the relationships between home language exposure, test performance and teacher and parent ratings of school-age Irish-English bilinguals. Language and Education, 1-20.

Ó Catháin, B. (2016). The Irish Language in Present-day Ireland. In R. Hickey (Ed.), Sociolinguistics in Ireland (pp. 41-59). London, UK: Palgrave Macmillan.

O'Toole, C. and Fletcher, P. (2012). Profiling vocabulary acquisition in Irish. Journal of Child Language, 39, 205220.

O'Toole, C. and Hickey, T. (2016). Bilingual language acquisition in a minority context: using the Irish-English Communicative Development Inventory to track acquisition of an endangered language. International Journal of Bilingual Education \& Bilingualism, 20(2), 146-162.

Paradis, J., Genesee, F., \& Crago, M. (2011). Dual language development and disorders: A handbook on bilingualism and second language learning. ( $2^{\text {nd }}$ ed.). London: Paul Brookes Publishing. 
Peña, E., Gillam, R., \& Bedore. L. (2014). Dynamic assessment of narrative ability in English accurately identifies language impairment in English language learners. Journal of Speech, Language, \& Hearing Research, $57,2208-2220$.

Péterváry, T. Ó Curnáin, B. Ó Giollagáin, C. and Sheahan, J. (2014). Iniúchadh ar an gCumas Dátheangach; An Sealbhú teanga i measc ghlúin óg na Gaeltachta. Analysis of Bilingual Competence; Language acquisition among young people in the Gaeltacht. Dublin: An Chomhairle um Oideachas Gaeltachta \& Gaelscolaíochta.

Pinto, G., Tarchi, C., \& Bigozzi, L. (2018). Promoting narrative competence in kindergarten: an intervention study. Early Childhood Research Quarterly, 47, 20-29.

Rethfeld, W. (2019). Speech and language therapy services for multilingual children with migration background: a cross-sectional survey in Germany. Folia Phoniatrica et Logopaedica, 71, 116-126.

Roch, M., Florit, E., \& Levorato, C. (2016). Narrative competence of Italian-English bilingual children between 5 and 7 years. Applied Psycholinguistics, 37(1), 49-67.

Stein, N.L. \& Glenn, C.G. (1979). An analysis of story comprehension in elementary school children. In R. Freedle (ed.). Discourse processing: Multidisciplinary perspectives (pp. 53-120). Norwood, NJ: Ablex.

Wiefferink, K., van Beugen, C., Sleeswijk, B., \& Gerrits, E. (2020). Children with language delay referred to Dutch speech and hearing centres: caseload characteristics. International Journal of Language \& Communication Disorders. doi: 10.1111/1460-6984.12540. 